Journal of Economics and Behavioral Studies (ISSN: 2220-6140)

Vol. 8, No. 5, pp. 39-55, October 2016

\title{
The Determinants of Non-Performing Loans in the 'MINT' Economies
}

\author{
Akinola Ezekiel Morakinyo, Mabutho Sibanda \\ University of KwaZulu Natal, Westville Campus, Durban, South Africa \\ akinmorakinyo@yahoo.com, sibandam@ukzn.ac.za
}

\begin{abstract}
This paper investigates the major determinants of non-performing loans in the MINT (Mexico, Indonesia, Nigeria and Turkey) economies. Identifying major determinants of non-performing loans, which are observed to be growing in these countries in recent time, will also guide policy and forecasting future levels that will be useful for pre-emptive policies and actions. It uses static panel data and dynamic panel model analyses. Evidence suggests that in the four economies, capital adequacy ratio, liquidity ratio, total bank credit andreturn on assets are significant bank-specific determinants of non-performing loans. Also, while the return on assets, liquidity ratio and capital adequacy ratioshow a negative and significant relationship with non-performing loans, nominal exchange rate, money supply growth rate, total bank credit and lending rate show positive and very significant relationships with non-performing loans. Finally, corruption, an institutional variable, shows a very strong positive relationship with non-performing loans.
\end{abstract}

Keywords: MINT, non-performing loans, determinants, panel, corruption

\section{Introduction}

Background: The acronym 'MINT', which was first coined by British economist Jim O'Neill, former chairman of Goldman Sachs Asset Management, represents Mexico, Indonesia, Nigeria and Turkey. O'Neill had come up in 2001 with the now-popular BRIC acronym (hitherto unknown), which later in 2010 got extended with the letter 'S' to make it BRICS (Brazil, Russia, India, China and South Africa). BRICS countries later organised themselves into a political and economic alliance. O'Neill (2014), after the11 September 2001 terror attacks, had the conviction that Europe and the United States (US) were confronted with economic decline. In his opinion, developing countries could benefit enormously from globalisation and fire-up the global economy. Common and major drivers of the prospects for the MINT economies include young and expanding populations. In theory, this is expected to lead to a persistent boost to domestic consumption, contrary to the demography of countries such as China with an ageing population. For instance, in 2013, Turkey's economy grew 10.3\% faster than China's, and was the third fastest growing world economy (World Bank, 2014). Economic growth came mainly from construction (6\%) rather than exports, such as in China and Russia. In addition, the MINT countries are at an advantage due to their respective geographic positions. Mexico benefits from increasing demand for exports from the US in recent years, Indonesia in Asia is in contiguity with the likes of China and Australia, Nigeria even though in West Africa can easily be a pivot of Africa's economy, while Turkey in the European Union, is positioned as an access point into Asia and Africa (Akpan, Isihak \& Asongu,2014).

Non-performing loans (NPLs) have been identified as a factor that limits the effectiveness of the banking sector in promoting the economic growth (see Boudriga, Taktak \& Jellouli, 2010). In the global financial stability report of International Monetary Funds (IMF), NPLs' level was seen as an old risk presenting new challenges and countries with high NPLs incidents have been advised to examine some factors that might be responsible for the upsurge in the cases of NPLs while those with relatively low incidents are encouraged to press harder in order to get better (IMF, 2013). The burden of NPLs reduces liquidity and causes low profitability in banks, limits credit expansion to viable economic entities, and confines economies to low growth as the real sector slows down with the attendant rise in unemployment. Unfortunately, credit, which sometimes births NPLs, is the oil that greases economies and is unavoidable (Klein, 2013). Even though the definition of NPLs is not uniform across countries, the IMF (2004) provided a definition that represents a general convergence of the term. A loan is deemed to be non-performing if payments (principal and/or interest) due have not been paid for at least 90 days. The Bank for International Settlements (BIS) 5 -tier 
system classifies loans into five categories: pass, special mention, sub-standard, doubtful and virtually lost. Of these, the last three classes of loans are the non-performing loans. While the first category refers to a healthy loan, special mention loans may currently have no outstanding payments but collections problems may be foreseen. However, the term 'impairment' is used in place of the term 'non-performing' by international accounting and banking standards. Sound Practices 7 and 11 of the Basel Committee on Banking Supervision and the International Accounting Standard (IAS) 39 refer to such loans as being impaired.

Just like Mexico, Indonesia, Nigeria and Turkey (MINTs or MINT countries), BRICS were a set of newly industrialised and developing countries, which were identified for their fast growing economic potentials. In the Goldman Sach's projections in 2006, by 2050, Mexico, Indonesia, Nigeria and Turkey are expected to rank 5 th, 7 th, 11 th and 14 th respectively by 2050 . The MINT countries have some attributes in common. They are all emerging economies that lie between 15th and 21st place in the world in terms of Gross Domestic Product (GDP) and all have population and geographical location advantages. All the MINT countries have youthful and expanding populations. Even though the largest four emerging market-developing economies are BRIC, and the next four are South Korea, Mexico, Indonesia and Turkey, Nigeria is justifiably included with the other three countries in this batch of countries. The reason is that Nigeria is within the ten Big Emerging Market (BEM) with the largest economy in Africa and regarded both a regional power in Africa and middle power in international affairs. Also, Nigeria could grow at an average minimum of $5 \%$ over the next 35years up to 2050 while established emerging economies such as China is expected to moderate to between $3 \%$ and $4 \%$ over the same period (PWC, 2015). Their model predicts Nigeria having the highest GDP growth rate over the same period of $5.4 \%$ in domestic currency. Although, other problems confronting the MINT economies include mammoth bribery and corruption, poor infrastructure development, weak institutions, governance issues, high levels of debt, and inadequate education systems, it is believed that if the problem of nonperforming loans can be fixed, banks will be in a more pole position to provide the needed catalyst for boosting the growth of these economies, and consequently push these economies to a higher level of growth (International Monetary Fund (IMF), 2013).

Myriads of studies preceded the first official meeting of BRIC in 2009 in Russia. For instance, in projecting the pathway for economies till 2050, Wilson \& Purushothaman (2003) suggested that the G6 could have a smaller economy than BRIC in US Dollar terms by as early as 2039. This study and some others before it seek to be a part of pioneers on MINTs. For instance, Akpan et al. (2014) studied the determinants of FDI in Fast-Growing Economies, comparing the BRICS and the MINTs. Durotoye (2014) analysed the MINTs as a possible emerging economic power bloc, putting into focus the crisis of youth unemployment. Öztürk \& Yildirim (2015) obtained ambiguous results in their test of the evidence of long-run panel causality test in the study of environmental Kuznets curve hypothesis in the MINT Countries. Asongu \& Kodila-Tedika (2015) compared the drivers of growth between the BRICS and the MINT countries. Finally, Kokotović \& Kurečić (2016) analysed the basic economic trends in the MINT countries and obtained results that seem to suggest a significant role in international relations as regional powers for the MINT countries. NPLs have been identified as the main cause of banking system crises in these countries (See Desmet, 2000; De Luna-Martinez, 2000, for Mexico; Fofack, 2005; Carney, 2009, for Indonesia; Aminu, Dogarawa \& Sabari, 2014; Adeyemi, 2011; Somoye, 2010, for Nigeria; Karabulut, Bilgin \& Danisoglu, 2010; Özatay, Sak, Garber \& Ghosh, 2002, for Turkey).

Furthermore, of concern is the fact that despite efforts by these countries, NPLs have been rising again. In spite of this realization by administrators of these economies, policies have failed to rein-in this problem as NPLs persist, rising over the last 4 years (after 2010 to 2014) by about 159\%, 191\%, 206\% and 106\% (but $153 \%$ in the last 3 years) in Mexico, Indonesia, Turkey and Nigeria respectively in absolute terms. This portends a real lurking danger to MINTs' financial stability and economic growth when juxtaposed to international benchmark of a maximum of 5\% annual growth of NPLs (Anderson, 2011). Facing this situation by economies identified for their potentials and future role in global economy puts this perspective in probable jeopardy and requires attention. The projection set by the IMF and others thus appears to be severely threatened with this trend for the MINT countries as only an efficient banking sector can provide enough credit flow to drive investment and economic growth. Therefore, it is believed that if the factors that determine non-performing loans can be thoroughly examined, it will provide insight into ways in which the rising trend of non-performing loans in the MINT countries can be pegged back ( $\mathrm{Hu}, \mathrm{Li} \& \mathrm{Chiu}, 2004$ and Fofack, 2005), ultimately paving the way for pre-emptive policies and actions. Consequently, the major 
objective of this study is to identify those important factors that determine non-performing loans and their individual relative impacts in MINTs, whose realisation of potentials, hinges on a healthy banking system. This study contributes to the existing literature by providing evidence on the determinants of NPLs in MINT countries, using the institutional variable (corruption) which had never been used in similar studies on these countries in the past. Moreover, MINTs is a relatively new economic bloc conception that so far has not enjoyed much attention from researchers. As far as we know, this is the first study of non-performing loans in the MINT economies as a 'bloc'.

\section{Literature Review}

The importance of credit to an economy cannot be over-emphasized. Friedman (1994) argues that a measure of credit is associated with nominal GDP, while Stiglitz (1989) maintains that money is important because of its relationship with credit. The institutional link between money and credit is enabled by the development of fractional reserve banking which combines loans with deposits (Cochran \& Call, 2000). Moinescu (2012) argues that strong increases and decreases in credit are the transmission channel of the dynamics of nonperforming loans. This corroborates the work of Jakubik \& Moinescu (2015) who link contracting credit to the growth of NPLs, likening it to inefficient resource allocation by banks. He further linked the dynamics of NPLs to the difference in banks' credit to the private sector, which is measured as a percentage of GDP. He argues that some macroeconomic variables as well as market variables determine the size of NPLs. In his opinion, macroeconomic variables such as economic growth enhance the capacity to repay. Conversely, financial market variables such as the exchange rate and interest rates lower capacity for repayment. In modelling credit, Zeng (2012) views loans to the economy as boosting total consumption and hence yielding a positive social utility, while NPLs are viewed as a source of financial pollution, which negates social utility. He identifies two economic implications of NPLs. Firstly, economic growth could decline if NPLs grow, causing resource allocation inefficiency. Secondly, capital requirements will increase as a result of the growth of NPLs as erosion of capital occurs due to funds being trapped in entities, making it impossible for the banks to fund new, economically viable ventures.

In terms of empirical studies, Studies on NPLs can be divided into five categories. The relevant tranche of literature to this study views NPLs at macroeconomic level across countries using the aggregate level of NPLs. Under this tranche, disaggregation of loan types across sectors within a group of countries is sometimes done in order to view NPLs irrespective of the category of determinants. The proposed study falls partially into this category. For instance, Beck, Jakubik \& Piloiu (2013) investigated the macroeconomic determinants of NPLs in a group of 75 countries using 10-year data. Using panel data analysis as the estimating technique, they first selected possible factors based on theory and a priori expectation. Their results, which are robustly validated using the Random effect model framework, suggest that significant determinants of NPLs are the lending rate, the exchange rate, the real GDP growth rate and share prices. In terms of share prices, greater impact was found in countries with a larger stock market relative to GDP ratio. For the exchange rate, countries with managed or pegged exchange rate systems seem to have unhedged borrowers of foreign exchange and this determines the direction of the effect on NPLs. Makri, Tsagkanos \& Bella (2014) studied the determinants of NPLs in the banking system of 14 countries in the Euro zone covering a period of nine years focusing on both bank-specific and macroeconomic variables. The study used the aggregate level of NPLs and employed the difference Generalized Method of Moments (GMM) as the estimating technique. The results suggest that there is a significant relationship between NPLs and macroeconomic variables such as unemployment, public debt, and the GDP growth rate. The study also found that bank-specific variables such as capital adequacy ratio, return on equity and NPLs of the previous year contributed significantly to the level of NPLs.

Financial Crisis and NPLs: Economic depressions trigger the level of NPLs and the deterioration in economic fortune shoots up the risk of non-performing loans (Sinkey and Greenawalt, 1991). The world has witnessed more financial crisis in the last ten years probably as a result of liberalization of financial systems (Yang, 2003). In the wake of the 1997 Asian financial crisis, there had been a rapid rise in the level of NPLs across those economies (Wade, 1998; Yang, 2003). Further worsening of NPLs' level accompanies financial crisis (Louzis et al., 2012). But some researchers are of the opinion that the beginning of a financial crisis can be highlighted by a rise in NPLs' level (Reinhart \& Rogoff, 2010). NPLs in any economy, is one of the drivers of banking crises. Banks can create money through credit expansion to the system and also make significant 
portion of their earnings through loan creation (Vodova, 2011). Banks undertake different risks in order to remain in business, but a credit risk which is positively related to banking crises, is the main risk carried by banks (Yang, 2003; Fofack, 2005). Credit risk is the risk that borrowers may not pay back, thereby, making loans become NPLs. NPLs reflect the stability of the banking system and largely the financial system since historically, a built-up level of NPLs has often been found to be associated with banking crises (Fofack, 2005). This relationship is established in the East Asian banking and financial crisis of 1997, which severely affected economic growth in Thailand, Indonesia, Malaysia and Korea, when more than 300 percent increase in NPLs level preceded the crisis (Mishkin (1999). Reinhart \& Rogoff (2010) further link financial crisis with sovereign debt crisis as was the case in Greece. Barseghyan (2010) also argued that the huge level of NPLs in Japan accounts in part towards the prolonged slowdown in that economy for over a decade till 2003. Finally, the global financial market instability of 2007 was triggered by mortgage defaults, which started from the United States of America (USA) mortgage market. The severity of the later spread to different countries of the world then depended on each country's cross-border financial exposure and link to the USA (Leaven \& Valencia, 2010).

\section{Methodology}

Model Specification: It is typical of non-performing loans' empirical models to include macroeconomic and bank-specific variables. Representing the work of Moinescu (2012) in functional form, we have:

NPLs $=\mathrm{f}($ credit accelerator, macro, market $)$

Suppose $\beta$ is the coefficient of 'macro', then, $\beta<0$. Also, suppose $\alpha$ is the coefficient of 'market', then, $\propto>0$.

According to Moinescu, a credit accelerator is made up of important components such as credit flow (F), liquidity ratio $(\mathrm{L})$ and inflation rate. That is:

$\mathrm{C}_{\mathrm{i}, \mathrm{t}}=\mathrm{f}\left(\mathrm{F}_{\mathrm{it},} \mathrm{L}_{\mathrm{i}, \mathrm{t}}, \pi_{\mathrm{i}, \mathrm{t}}\right)$

Few studies that have included institutional variables such as Ahmad (2013) and Goel \& Hasan (2011) find the same relationship as 'market' with the level of NPLs.

Hence, our model, is therefore hypothesised as follows:

bnpl $_{i, t}=f\left(\right.$ bcar $_{i, t}$, btcr $_{i, t}$, roa $_{i, t}$, roe $_{i, t}$, blr $_{i, t}$, ledr $_{i, t}$, exr $_{i, t}$, infr $_{i, t}$, msgr $_{i, t}$, gdpgr $\left._{i, t}, \operatorname{crptn}_{i, t}\right)$

Where all variables are as defined in section 3.5.

We consider two main estimating techniques under static panel data analysis and a dynamic panel data estimating technique. The first one is a fixed effects model (FEM) ('within group' and Least Squares Dummy Variable). This allows us to control for unobserved heterogeneity across the MINT countries. But this technique may yield biased results if fixed effects, $\pi_{i}$, is correlated with error term, $\mu_{i t}$. We proceed to estimate the second technique known as the random effects model (REM), which is only appropriate if we think that $\operatorname{Cov}\left(\pi_{\mathrm{i}}, \mathrm{X}_{\mathrm{it}}\right)=0$. We then conclude by obtaining the results of dynamic estimation utilising systemic generalised method of moments (GMM), which helps to overcome the presence of possible endogeneneity in our static model through the use of instrumental variables.

Estimation Technique: Panel data analysis: Panel models are basically divided into two: one is the static panel model while the other is the dynamics panel model (Bai, 2009). Fixed effect ('within group' (WG) and least square dummy variable (LSDV)) and random effects are the two static panel models available in the panel literature (Hedges \& Vevea, 1998; Rowland \& Torres, 2004). The literature has supported usage of fixed effect (WG) because it is capable of producing what is called consistent estimators, the reason being that values are differenced around their various sample means (Blundell, Bond \& Windmeijer, 2000). In the case of fixed effect, LSDV cross-sectional variation is allowed through the use of dummy variables (Kezdi, 2004; Andrews, Schank \& Upward, 2006). However, Gujarati and Sangeetha(2007) and Hayes and Preacher(2013) cautioned that when the dummy variables become too many, the degree of freedom that is consumed is too much and this will have serious implicationsfor the result.

The equation of fixed effect is given as:

$Y_{i t}=X_{i t} \beta+\pi_{i}+\mu_{i t}$ 
Where intercept is not expressly stated, $y_{i t}$ is the vector of bank non-performing loans, bnpl, across the MINT countries, $\pi_{i}$ is the unobserved country-specific effect, $\beta$ is a vector of parameter estimates for each of the explanatory variables and the constant, $x_{i t}$, is a K-dimensional row vector of explanatory variables $\left(\right.$ bcar $_{i, t}$, btcr $_{i, t}$, roa $_{i, t}$, roe $_{i, t}$, blr $_{i, t}$, ledr $_{i, t}$, exr $_{i, t}$, infr $_{i, t}$ msgr $_{i, t}$, gdpgr $\left._{i, t}, \operatorname{crptn}_{i, t}\right)$ as defined in section 3.5 over the time period that variables were observed, and $\mu_{i t}$ is the error term.

For the LSDV equation, we have the following:

$y_{i t}=\sum_{j=2}^{4} D_{j}+X_{i t} \beta+\pi_{i}+\mu_{i t}$

Where $D_{j}$ represents the dummy variables for $\mathrm{N}-1$ cross-section of countries. This is the only addition to equation (2). This means we have 'dummyindonesia', 'dummynigeria', and 'dummyturkey' in the equation with Mexico being the reference for the others. In other words, other country dummies give intercepts relative to the intercept of Mexico.

However, there is the possibility of a multicollinearity problem if the dummy variables are too many and this may lead to an endogeneity problem where regressors can be correlated, thus leading to bias and an inconsistent estimator (Gujarati\& Sangeetha, 2007). For the random effect model (REM), developed by Nerlove \&Balestra (1996), this aims to account for the possible variable omission in the fixed effects model. The basic equation for the random effect model is presented thus:

$y_{i t}=\alpha+X_{i t} \beta+\pi_{i}+\mu_{i t}$

Where $y_{i t}$ is a vector of bank non-performing loans, bnpl, across MINT countries, $\alpha$ is the constant, $\beta$ is a vector of parameter estimates for each of the explanatory variables, $x_{i t}$ is a K-dimensional row vector of explanatory variables $\left(\right.$ bcar $_{i, t}$, btcr $_{i, t}$, roa $_{i, t}$, roe $_{i, t}$, blr $_{i, t}$, ledr $_{i, t}$, exr $_{i, t}$, infr $_{i, t}$ msgr $_{i, t}$, gdpgr $_{i, t}$, crptn $\left._{i, t}\right)$ as defined in section $3.5, \pi_{i}$ is within-entity error, and $\mu_{i t}$ is between-entity error. Under REM, we assume that $\pi_{i}$ is random and does not correlate with the explanatory variables.

The Hausman (1978) test is utilised in this study on the appropriateness of either the FEM or REM (see Mutl \&Pfaffermayr, 2011).

This study also explores the dynamic panel data approach (see Arellano \&Bond, 1991; Eigner, 2009). This method, called the generalised method of moments (GMM) generates a model that improves the performance of the estimator.

The equation of the GMM is thus:

$y_{i t}=X_{i t} \beta_{1}+W_{i t} \beta_{2}+\varepsilon_{i t}$

Where $y_{i t}$ is the vector of bank non-performing loans, bnpl, across the MINT countries, $W_{i t}$ is the vector of predetermined regressors including lag(s) of $\mathrm{y}$, intercept, $\beta_{i}$ for $i=1,2$ are parameter estimates for each of the explanatory variables, $x_{i t}$ is a K-dimensional row vector of strictly exogenous explanatory variables as defined in section 3.5 over the time period that variables were observed, and $\varepsilon_{i t}=\pi_{i}+\mu_{i t}$ is the error term.

This equation is just a modification of the fixed effect equation with the inclusion of instrumental variables. However, system-GMM by Blundell \&Bond (1998) and Blundell et al. (2000) was used as this approach completely eliminates the problem of weak instrumental variables, which may be possible in the GMM version of the dynamic panel data by Arellano-Bond particularly as variables approach a random walk. Another advantage of system-GMM it gives room for the inclusion of time-invariant regressors which disappears in Difference-GMM. System-GMM uses additional restrictions by using modified instruments with lagged differences in addition to lagged levels used by Arellano-Bond.

Data: Data on bank non-performing loans for the MINT countries were sourced from the Reserve Bank of St. Louis database. Data on national basis, on official exchange rate, GDP growth rate, money supply growth rate, inflation rate, total bank credit to domestic economy, bank liquidity ratio, bank capital adequacy ratio, return on assets, return on equity, lending rate (for Mexico, Indonesia, Nigeria and Turkey) were sourced from the World Bank Tables 2013 edition and reported. The database of Transparency International supplied the CorruptionPerceptionIndex (CPI) for the countries. The database for the Central Bank of Turkey is the source 
for the lending rate of Turkey. The scope of data was 17 years (1998-2014) for all countries. Data are scooped on a quarterly basis and the likes of the Corruption Perception Index, which is only available annually, were interpolated as in Chow and Lin (1971) and Auffhammer, Hsiang, Schlenker, \& Sobel (2013). The main limitation of this study relates to reliability of data, particularly on non-performing loans arising from representative bias as Bankscope publishes aggregate country data once data from at least four banks is received (Breuer, 2006). However, the most accurate data for NPLs are available from 1996 (Greenidge \&Grosvenor, 2010; Hasan \&Wall, 2004. Our data set starts from 1998 to mitigate this limitation.

Variables identification and empirical relationship: The selection of variables for this study is based on theory and previous empirical work. The bank capital adequacy ratio (bcar), which is a bank-specific variable, is used as in Sinkey \& Greenawalt (1991) and Berger \& DeYoung (1997). Berger and DeYoung (1997) found an inverse relationship between the level of non-performing loans and the bank capital adequacy ratio. The banks' credit to the economy, a bank-specific variable, was used in the work of Boudriga et al., (2010) where an inverse relationship was suggested. As a proxy for bank performance, Fofack (2005) and Godlewski (2006) used return on assets, 'roa' (we have also included return on equity, 'roe'), and found a negative relationship between non-performing loans and roa, which is a bank-specific variable. Also, one important determinant of bank performance is the bank liquidity ratio. Jiménez, Ongena, Peydró \& Saurina (2014) linked this with non-performing loans and we have included this as a bank-specific variable. As a macroeconomic variable, lending rate was used by Nkusu (2011) and Fofack (2005) who find a direct relationship with non-performing loan levels. Krueger and Tornell (1999) and Benavente, Johnsonand Morande, (2003) linked the exchange rate and non-performing loans, and this has also been included as a macroeconomic variable. Makin (2007) linked money supply to non-performing loans and thus we have included its growth rate in this study as a macroeconomic variable. The GDP growth rate, a macroeconomic variable, has also been selected and this is following the work of Kruegerand Tornell (1999), Louzis, Vouldis and Metaxas, (2012) and Fofack (2005), who find a negative relationship between economic growth and nonperforming loans. The level of corruption (see Boudrigaet al., 2010; Ahmad, 2013; Goeland Hasan,2011) captured by Corruption Perception Index, represents an institutional variable used in this study. There seems to be unanimity in previous empirical studies that there is a direct relationship with non-performing loans.

Variables definition and measurement: Where bnpl is the total bank non-performing loansmeasured as a percentage of gross loans;

bcar isthe capital adequacy ratio measured as the bank capital to asset ratio;

btcr isthe banks' total credit to private sector measured as a percentage of GDP;

roa isthe banks' return on assets measured as an average period percentage;

roe is the banks' return on equity measured in average period percentages;

$b l r$ is the annual banks' liquidity reserve as a percentage of bank assets;

ledr isthe lending rate measured in average period percentage;

exr isthe official exchange rate measured in local currency per US\$, period average;

$m s g r$ isthe money supply growth rate (broad money growth in average period percentage);

infr isthe inflation rate measured as consumer price inflation in average period percentage;

gdpgr isthe GDP is the growth rate of Gross Domestic Product;

crptn isthe corruption index for each average period measured from $1=$ low to $10=$ high.

\section{Results and Discussion}

This section of the research work explains the empirical results and findings. It contains the panel estimation results as well as the dynamic panel model results. Basic inferences are made after the discussion of the results. The first aspect explains the descriptive analysis. 
Table 1: Fixed effect within group result

\begin{tabular}{lll}
\hline Variable & Coefficient & p-value \\
\hline Capital adequacy ratio & $-0.787^{* * *}$ & 0.000 \\
Bank liquidity & -0.052 & 0.464 \\
Total bank credit & $0.164^{* * *}$ & 0.001 \\
Return on assets & $-1.346^{* * *}$ & 0.000 \\
Return on equity & $0.015^{* * *}$ & 0.291 \\
Exchange rate & $0.002^{* * *}$ & 0.003 \\
Inflation rate & -0.032 & 0.705 \\
Lending rate & $0.190^{* *}$ & 0.038 \\
Money supply growth rate & $0.073^{* *}$ & 0.031 \\
GDP growth rate & -0.056 & 0.444 \\
Corruption & $-9.309^{* * *}$ & 0.000 \\
Constant & 33.360 & 0.000 \\
\hline
\end{tabular}

Note: * represents significance level of $10 \%$, ** represents significance level of $5 \%$ and *** represents significance level of $1 \%$. R-square: Within $=0.745$, Between $=0.570,0$ verall $=0.436$, corr $\left(u_{-} \mathrm{i}, \mathrm{Xb}\right)=-0.857$. F statistic: $F(11,241)=63.87$,Prob $>F=0.000$, rho $=0.898$

Source: Author's computation

Table 2: Random effect result

\begin{tabular}{lll}
\hline Variable & Coefficient & p-value \\
\hline Capital adequacy ratio & $-0.755^{* * *}$ & 0.000 \\
Bank liquidity & -0.103 & 0.119 \\
Total bank credit & $0.218^{* * *}$ & 0.000 \\
Return on assets & $-1.064^{* * *}$ & 0.000 \\
Return on equity & 0.013 & 0.335 \\
Exchange rate & $-0.000^{*}$ & 0.080 \\
Inflation rate & 0.019 & 0.806 \\
Lending rate & $0.319^{* * *}$ & 0.000 \\
Money supply growth rate & $0.065^{*}$ & 0.061 \\
GDP growth rate & -0.064 & 0.377 \\
Corruption & $-6.808^{* * *}$ & 0.000 \\
Constant & 29.487 & 0.000
\end{tabular}

Note: ${ }^{*}$ represents significance level of $10 \%,{ }^{* *}$ represents significance level of $5 \%$ and ${ }^{* * *}$ represents significance level of $1 \%$. R-square: Within $=0.722$, Between $=0.992$, Overall $=0.783$, corr $\left(\mathrm{u}_{-} \mathrm{i}, \mathrm{X}\right)=0$ (assumed). Wald chi2(11) $=882.31$,Prob $>$ chi2 $=0.0000$, rho $=0$

Source: Author's computation

Table 3: Hausman test result

\begin{tabular}{lllll}
\hline Variable & $\begin{array}{l}\text { (b) } \\
\text { Fixed }\end{array}$ & $\begin{array}{l}\text { (B) } \\
\text { Random }\end{array}$ & $\begin{array}{l}\text { (b - B) } \\
\text { difference }\end{array}$ & $\begin{array}{l}\text { Sqrt(diag(V_b-V_B)) } \\
\text { standard error }\end{array}$ \\
\hline Capital adequacy ratio & -0.787 & -0.755 & -0.031 & 0.000 \\
Bank liquidity & -0.052 & -0.103 & 0.051 & 0.026 \\
Total bank credit & 0.164 & 0.218 & -0.054 & 0.032 \\
Return on assets & -1.346 & -1.064 & -0.282 & 0.014 \\
Return on equity & 0.015 & 0.013 & 0.001 & 0.002 \\
Exchange rate & 0.002 & -0.000 & 0.0025 & 0.001 \\
Inflation rate & -0.0318 & 0.019 & -0.050 & 0.036 \\
Lending rate & 0.190 & 0.319 & -0.129 & 0.052 \\
Money supply growth rate & 0.073 & 0.065 & 0.008 & 0.000 \\
GDP growth rate & -0.056 & -0.064 & 0.008 & 0.000 \\
Corruption & -9.309 & -6.808 & -2.500 & 0.655 \\
\hline
\end{tabular}

chi2 $(11)=(b-B)^{\prime}\left[\left(V_{-} b-V_{-} B\right)^{\wedge}(-1)\right](b-B)=25.01$, Prob $>$ chi $2=0.0091$

Source: Author's computation 
Tables 1 and 2 contain the results of the panel model. Both the fixed and the random effects are reported, as the Hausman test shows that there is significant difference between the two. From the result of the Hausman test, we reject the null hypothesis that the random effects model is the appropriate model to use, and accept that the fixed effects model is the appropriate model to use. The use of FEM is further justified as it tackles the effect of heterogeneity which would have affected our results. All the same, all the variables that are significant in the REM are also significant in the FEM. The following variables, namely: capital adequacy ratio, corruption, lending rate, return on assets, total bank credit, exchange rate, and money supply growth rate, appear significant in both models. Both models suggest the nature of the relationship (that is direct or inverse) between each of the significant variables and non-performing loans. This is an indication that they are likely to be important determinants of non-performing loans in the MINT economies. However, to confirm their individual effect the dynamic panel model might be necessary. The R-square of the two models is good. The reason is that at least all the determinants account for above $70 \%$ variation in the non-performing loans of the four economies. To corroborate the R-square results, the two models are tested for overall significance through the F-test for fixed effect and chi square test for the random effect. The results show that the two models pass the test of overall significance. This shows that the choice of variables used as determinants appears to be appropriate. Furthermore, empirical literature has shown that there is a possibility of crosssectional dependence in panel results, and this necessitates the need to conduct the test of significant differences in intercepts of MINT countries using the fixed effect LSDV as shown below.

\section{Test of difference in intercepts of entities: Fixed effects LSDV (least square dummy variable)}

Table 4: Fixed effects LSDV result

\begin{tabular}{lll}
\hline Variable & coefficient & Standard error \\
\hline Capital adequacy ratio & $-0.787^{* * *}$ & 0.000 \\
Bank liquidity & -0.052 & 0.464 \\
Total bank credit & $0.164^{* * *}$ & 0.001 \\
Return on assets & $-1.346^{* * *}$ & 0.000 \\
Return on equity & 0.015 & 0.291 \\
Exchange rate & $0.002^{* * *}$ & 0.003 \\
Inflation rate & -0.032 & 0.705 \\
Lending rate & $0.190^{* *}$ & 0.038 \\
Money supply growth rate & $0.073^{* *}$ & 0.031 \\
GDP growth rate & -0.056 & 0.444 \\
Corruption & $-9.309^{* * *}$ & 0.000 \\
Constant & $40.068^{* * *}$ & 0.000 \\
Country 2 & $-26.601^{* * *}$ & 0.001 \\
Country 3 & $-2.9865^{*}$ & 0.051 \\
Country 4 & $5.665^{* * *}$ & 0.001 \\
\hline
\end{tabular}

$\mathrm{F}(14,241)=70.38$, Prob $>\mathrm{F}=0.0000, \mathrm{R}$-squared $=0.8035$

Note: ${ }^{*}$ represents significance level of $10 \%,{ }^{* *}$ represents significance level of $5 \%$ and ${ }^{* * *}$ represents significance level of $1 \%$, Source: Author's computation

\section{Static Diagnostic tests}

Autocorrelation: We conduct the Wooldridge test for autocorrelation in panel data by testing the null hypothesis such that there is no first order autocorrelation. Since Prob $>$ F $=0.0001$, we reject the null and accept the alternative that there is autocorrelation.

Correlation in residuals: Using Pesaran's CD Test of cross-sectional independence, we investigated the correlation of residuals across entities. Confirmation of contemporaneous correlation using this test can lead to bias in test results. After testing the null hypothesis that there is no correlation in residuals across entities, we obtained a P value of 0.0054 . This result leads us to reject the null and conclude that there is evidence of contemporaneous correlation. 
Heteroscedasticity: We also investigated evidence of heteroscedasticity in the FEM in which errors are assumed to be independently distributed, making our standard error consistent in order to ensure valid statistical inference. We conducted the Modified Wald test for group-wiseheteroscedasticity with the null hypothesis that there is constant variance (homoscedasticity). The null hypothesis is rejected and we conclude that there is evidence of heteroscedasticity in the FEM.

Test of cross-sectional dependence: According to Batalgi (cited in Griffith \&Chun, 2014), cross-sectional dependence is a problem in macro panels with a long time series. The Breusch Pagan/LM test of independence is given as follows:

Table 5: Correlation matrix of residuals

\begin{tabular}{|c|c|c|c|c|}
\hline & _e1 & e2 & e3 & e4 \\
\hline _e1 & 1.0000 & & & \\
\hline _e2 & 0.1757 & -1.0000 & & \\
\hline _e3 & 0.2322 & -0.2517 & 1.0000 & \\
\hline _e4 & -0.1950 & -0.3644 & -0.2559 & 1.0000 \\
\hline
\end{tabular}

Based on the result obtained, we reject the null hypothesis and conclude that there is cross-sectional dependence. Also, as shown in Table 4, there is an indication of cross-sectional dependence in the result. All the four dummy intercept variables for each of the countries are statistically significant. Here, Mexico is used as the reference intercept for the intercept of the other countries. The implication is that there is presence of a cross-sectional specific factor that can have an influence on our result. Three of the significant intercepts are at $1 \%$ while one is at $10 \%$ giving a strong case for the element of cross-sectional dependence noticed in the panel. The implication for our findings is that individual countries in the MINT economies are likely to possess some peculiar structural and institutional differences that distinguish them from one another, and this can have implicationsfor our result. This is inline with the findings of some authors in the past who were of the opinion that most economic blocs, such as BRICS and the Organisation for Economic Co-operation and Development (OECD), do have individual peculiarities that distinguish them from one another. Therefore, the result shows that MINT is not an exception in this respect either (Pao, Lin or Chang, 2011). However, the LSDV result is also significant at $1 \%$ and the R-square is also relatively high showing that over $80 \%$ variation in the non-performing loans is explained by all the independent variables. It indicates that all the choice variables are most likely the core non-performing loans determinants in these economies.

Furthermore, as a result of the outcomes of some of the diagnostic tests conducted, we need to make some adjustments. For instance, when there is evidence of contemporaneous correlation of residuals in panels and autocorrelation, the use of the standard errors of Driscoll and Kraay (1998) is suggested as a robust standard error (Hoechle, 2007). Also, in a situation where heteroscedasticity is present in panels, it is suggested that the Huber/White, otherwise referred to as the Sandwich estimator, is used to derive heteroskedastic-robust standard errors. Alternatively, in addition to these problems as well as possible endogeneity in our model, panel model extension has made it possible to obtain more realistic results using the dynamic panel data. This will further help us to ascertain the level of consistency in the result and obtain more efficient estimators (see Arellano \& Bond, 1991). We therefore proceed to the dynamic panel data analysis. 
Table 6: Dynamic panel data result

\begin{tabular}{lllllll}
\hline Dynamic Panel (Arellano-Bond) & & & \multicolumn{4}{c}{$\begin{array}{l}\text { Systemic } \\
\text { (Blundell-Bond) }\end{array}$} \\
\hline Variables & Coefficient & S.E & p value & Coefficient & S.E & p value \\
bnpl (L1) & $0.7343^{* * *}$ & 0.0243 & 0.000 & $0.9527^{* * *}$ & 0.0151 & 0.000 \\
bcar & -0.0203 & 0.0529 & 0.701 & $0.0989^{* * *}$ & 0.0137 & 0.001 \\
Liquidity & $0.0484^{* *}$ & 0.0227 & 0.033 & $-0.0596^{* * *}$ & 0.0137 & 0.000 \\
Corruption & -0.3262 & 0.4497 & 0.468 & 0.3017 & 0.2122 & 0.155 \\
Lending rate & 0.0280 & 0.0337 & 0.405 & $0.0874^{* * *}$ & 0.0166 & 0.000 \\
Inflation rate & $-0.0728^{* * *}$ & 0.0271 & 0.007 & $-0.1745^{* * *}$ & 0.0166 & 0.000 \\
return on assets & $-1.0885^{* * *}$ & 0.0856 & 0.000 & $-0.2739^{* * *}$ & 0.0370 & 0.000 \\
return on equity & $0.0565^{* * *}$ & 0.0052 & 0.000 & $0.0134^{* * *}$ & 0.0020 & 0.000 \\
GDP Growth Rate & 0.0381 & 0.0249 & 0.126 & $-0.0233^{*}$ & 0.0122 & 0.056 \\
Bank Total credit & $0.0618^{* *}$ & 0.0246 & 0.012 & 0.0063 & 0.0151 & 0.678 \\
Exchange rate & $0.0009^{* * *}$ & 0.0003 & 0.000 & 0.0001 & 0.0000 & 0.104 \\
Money Supply growth rate & 0.0028 & 0.0103 & 0.784 & $0.0420^{* * *}$ & 0.0083 & 0.000 \\
Constant & -0.6339 & 1.6548 & 0.702 & -0.9954 & 0.7981 & 0.212 \\
\hline
\end{tabular}

Note: ${ }^{*}$ represents significance level of $10 \%,{ }^{* *}$ represents significance level of $5 \%$ and ${ }^{* * *}$ represents significance level of $1 \%$

Source: Author's computation

Dynamic panel data: This study employs systemic GMM, which is generalised method of moments, to analyse the dynamic panel data. Aside from being able to deal with endogeneity issue in the dataset used in the study, the choice of SYS GMM is based on Hsiao \& Tahmiscioglu (2008) who were of the opinion that the selection of instrumental variables under the GMM, that is the Arellano and Bond (1991) version, is not completely appropriate. They advise the use of SYS GMM, which is the version of Blundell and Bond (1998) for dynamic panel data. Endogeneity always arises from error in measurement, simultaneity and omitted variable. Just as in Louzis et al. (2012), we identify bank-specific variables as sources of endogeneity using internal instruments but acknowledge that identifying instrumental variables that are valid is a challenge in econometrics. Maddala (1977) queries where such variables could come from (Larcker \& Rusticus, 2010). All the same, the result of both versions for our study shows the use of instruments to deal with endogeneity as contained in Table 6.

The result of the SYS GMM in Table 6 also confirms that many of the variables that were found to be significant in the static panel model are also significant in the SYS GMM. Notwithstanding, the SYS GMM result further shows that liquidity ratio, inflation rate and GDP growth rate have joined the pool of variables that may constitute major determinants of non-performing loans in the MINT economies. A growing nonperforming loans level stunts growth as allocated resources are trapped with unproductive economic agents (Keeton \& Morris; 1987; Krueger \& Tornell, 1999; Fofack, 2005; Louzis et al., 2012; Škarica, 2013). When the economy is growing, with likely associated income rise, financial capacity which reduces economic burden is enhanced and this in turn is expected to reduce financial distress (also see Nkusu, 2011). Also, since bank performance has an influence on risk-taking by managers, this is corroborated by the significance of the ROE as a determinant of non-performing loans(Fofack, 2005).Furthermore, as in Makri et al. (2014), the level of NPLs in the previous year is found to be positively significant in determining the NPLs level. In conclusion, capital adequacy ratio, liquidity ratio, return on assets, exchange rate, lending rate and GDP levels are major variables that have individual significant impact on the magnitude of non-performing loans in the MINT economies. But we need to conduct some tests on these results so that we can ascertain their validity.

Dynamic Diagnostic Test: We proceed to test for validity of instruments utilized in the model. This can be done using the Sargan Test even though Roodman (2009) cautioned about the use of this test when many instruments are utilised. The puzzle here is that what constitutes too many instruments is not clear in the 
literature (Ruud, 2000). The two important requirements of an appropriate instrumental variables are that of their orthogonality with the error term and correlation to the endogenous variable(s). The systemic dynamic panel data results can only produce the correct results given valid moment conditions. The validity of moment conditions can be tested only when they are overidentified and this cannot be tested when they are exactly identified in a model. The Sargan Test is that of the null hypothesis that the overidentifying restrictions are valid. Rejecting the null hypothesis means that our model's instrumental variables need to be reconsidered except we attribute the rejection to the presence of heteroscedasticity (Arellano and Bond, 1991). In our overidentified model with 163 instrumental variables generated, the result of the Sargan Test is produced Prob > chi $2=0.0000$. This leads us to reject the null hypothesis and accept the alternative hypothesis that the instruments used are invalid (http://www.stata-press.com/data/r13/abdata). As recommended by Baum, Schaffer, \& Stillman (2007). the validity of results should be doubted once the null hypothesis of Sargan Test is rejected.

We now turn our attention to generating standard errors that are robust for some reasons. Firstly, some underlying regression model assumptions are violated and this leads to invalid statistical inference culminating in invalid results obtained in the chosen fixed effect models. Secondly, our model is not dynamic in nature and instruments used for the systemic dynamic panel analysis has been found to be statistically invalid. In Hoechle (2007), 'White' standard errors help to obtain heteroskedasticity-consistent estimates. This robust estimate assumes that residuals are independently distributed and standard errors obtained are consistent even in spite of heteroskedastic residuals. The clustered standard error otherwise called Rogers further relaxes the assumption of independent distribution of residuals also helps to obtain heteroskedasticity and autocorrelation-consistent (HAC) estimates. Dealing with panel residuals that are temporal and spatially dependent as well as heteroskedasticity was earlier achieved with feasible generalized least squares (FGLS) otherwise known as Parks-Kmenta method. Standard error estimates obtained here are consistent to disturbances that are not homoscedastic, autocorrelated and contemporaneously crosssectionally autocorrelated. But this is deemed inappropriate for use in microeconomic panels that are not small because SE is either unacceptably small or $\mathrm{N}$ is greater than $\mathrm{T}$. The panel corrected standard errors (PCSE) of Beck and Katz (1995) demonstrates superiority in this manner to the FGLS. But Driscoll and Kraay (1998), making use of Newey-West standard error demonstrates more appropriateness of use when $\mathrm{N}$ gets large. The Newey-West estimator is the best HAC approach to an instrumental variable-GMM problem (Baum et al., 2007). Hence, we shall conduct these tests to obtain valid results and compare outcomes as follows:

Table 7: Robust result (1)

\begin{tabular}{lllllll}
\hline \multirow{2}{*}{$\begin{array}{llllll}\text { Estimating Technique } \\
\text { Variables }\end{array}$} & \multicolumn{3}{l}{$\begin{array}{l}\text { Standard Error adjusted for } \\
\text { 4 countries (FE ROBUST) }\end{array}$} & \multicolumn{2}{l}{$\begin{array}{l}\text { Robust Standard Error } \\
\text { (FE CLUSTER) }\end{array}$} \\
\hline bcar & Coefficient & S.E & p value & Coefficient & S.E & p value \\
Liquidity & $-0,787^{*}$ & 0,273 & 0,064 & $-0,787^{* * *}$ & 0,134 & 0,000 \\
Corruption & $-0,052$ & 0,074 & 0,531 & $-0,052$ & 0,071 & 0,464 \\
Lending rate & $-9,309^{* *}$ & 2,599 & 0,037 & $-9,309^{* * *}$ & 0,924 & 0,000 \\
Inflation rate & 0,190 & 0,145 & 0,282 & $0,190^{* *}$ & 0,091 & 0,038 \\
return on assets & $-0,032$ & 0,030 & 0,362 & $-0,032$ & 0,084 & 0,705 \\
return on equity & $-1,346^{*}$ & 0,501 & 0,075 & $-1,346^{* * *}$ & 0,213 & 0,000 \\
GDP Growth Rate & 0,015 & 0,030 & 0,664 & 0,015 & 0,014 & 0,291 \\
Bank Total credit & $-0,056$ & 0,213 & 0,811 & $-0,056$ & 0,073 & 0,444 \\
Exchange rate & $0,164^{*}$ & 0,057 & 0,064 & $0,164^{* * *}$ & 0,050 & 0,001 \\
Money Supply growth & $0,002^{* *}$ & 0,001 & 0,033 & $0,002^{* * *}$ & 0,001 & 0,003 \\
rate & & & & & & \\
Constant & $0,073^{* *}$ & 0,017 & 0,023 & $0,073^{* *}$ & 0,033 & 0,031 \\
sigma_u & 33,360 & 6,807 & 0,016 & 33,360 & 3,857 & 0,000 \\
\hline
\end{tabular}




\begin{tabular}{lll}
\hline sigma_e & 4,785 & $\begin{array}{l}4,785 \\
0.898 \\
\text { u_i) }\end{array}$ (fraction of variance due to \\
rho & 0,898 & \\
Wald chi2(11) & \\
Prob> chi2 \\
R-squared \\
$\begin{array}{l}\text { Note: }{ }^{*} \text { represents significance level of } 10 \%, * * \\
\text { significance level of } 1 \%\end{array}$
\end{tabular}

In our results under White standard errors that are robust to heteroscedasticity, bank capital adequacy, return on assets and corruption are statistically significant and have a negative relationship with level of NPLs. In contrast, lending rate, bank total credit to the private economy, exchange rate and money supply growth rate demonstrates positive relationship to NPLs levels and are statistically significant. The Rogers and FGLS produce similar results and fairly different significant levels on rare occasions. For instance, bank capital adequacy, return on assets and corruption (this seeming puzzle is explained below) are statistically significant and have a negative relationship with level of NPLs. In contrast, lending rate, bank total credit to the private economy, exchange rate and money supply growth rate demonstrates positive relationship to NPLs levels and are statistically significant. Under these estimates, lending rate is the only additional variable found significant compared to the White standard errors. Further, the Newey-West standard errors produced the results of Rogers and FGLS and in addition, a result that suggest that liquidity ratio has a statistically significant negative relationship with the NPLs levels. This is consistent with the literature that a higher level of liquidity in banks is accompanied by a lower level of NPLs (Jimenez et al., 2014). Conversely, the PCSEs produced results that are almost similar to Newey-West but different only in exchange rate which is insignificant but ultimately is of the same effect because the coefficients are both zero.

However, the individual relationship between the non-performing loans and each variable shows that the lending rate has a positive and significant impact on non-performing loans in the MINT economies. This result is similar as in some of the previous literature that postulates a direct relationship between the two. The idea, according to this literature, is that an increase in the lending rate leads to a rise in the non-performing loans because borrowers become more irresponsive to lending rate increases. Also, borrowers' debt servicing capacity is expected to be weakened by a high interest rate (see Nkusu, 2011; Fofack, 2005). Therefore, nonperforming loan is expected to show positive relationship with interest rate. Among the bank specific ratios, capital adequacy ratio appears to have one of the highest impacts on non-performing loans. It is significant in all the models. This is in support of literatures that tied non-performing loans to moral hazard (see Sinkey and Greenwalt (1991) and Berger and DeYoung (1997)). The implication is that the bank-specific factors such as capital adequacy ratio are an important variable that can be used to control the volume of non-performing loans in the banking sector (Louzis et al., 2012). According to Berger and DeYoung (1997) the importance of moral hazard is linked with the capital adequacy ratio, the higher the capital adequacy ratio the more guaranteed the corporate existence of the bank and the less the management tendency to go after low quality loan.

Table 8: Robust result (2)

\begin{tabular}{|c|c|c|c|c|c|c|c|c|c|}
\hline \multirow{4}{*}{$\begin{array}{l}\text { Estimating Technique } \\
\text { Variables }\end{array}$} & \multirow{3}{*}{\multicolumn{3}{|c|}{$\begin{array}{l}\text { Cross-sectional time-series } \\
\text { FGLS regression } \\
\text { Panels: Homoscedastic } \\
\text { Estimated Autocorrelation = } 0\end{array}$}} & \multicolumn{3}{|c|}{$\begin{array}{l}\text { Lin. Reg., correlated panels } \\
\text { corrected st.d errors (PCSEs) }\end{array}$} & \multicolumn{3}{|c|}{$\begin{array}{l}\text { Regr. with Newey-West } \\
\text { standard errors }\end{array}$} \\
\hline & & & & \multirow{3}{*}{ Coefficient } & \multirow[t]{3}{*}{ S.E } & \multirow[t]{3}{*}{ p value } & \multirow[t]{3}{*}{ Coefficient } & \multirow[t]{3}{*}{ S.E } & \multirow[t]{3}{*}{ p value } \\
\hline & & & & & & & & & \\
\hline & Coefficients & S.E & p value & & & & & & \\
\hline Bcar & $-0,755^{* * *}$ & 0,134 & 0,000 & $-0,755^{* * *}$ & 0,129 & 0,000 & $-0,755^{* * *}$ & 0,257 & 0,004 \\
\hline Liquidity & $-0,103$ & 0,064 & 0,111 & $-0,103$ & 0,062 & 0,099 & $-0,103^{*}$ & 0,061 & 0,092 \\
\hline Corruption & $-6,808^{* * *}$ & 0,637 & 0,000 & $-6,808$ & 0,475 & 0,000 & $-6,808^{* * *}$ & 0,705 & 0,000 \\
\hline Lending rate & $0,319^{* * *}$ & 0,073 & 0,000 & $0,319 *$ & 0,069 & 0,000 & $0,319^{* * *}$ & 0,103 & 0,002 \\
\hline
\end{tabular}




\begin{tabular}{llllllllll}
\hline Inflation rate & 0,019 & 0,074 & 0,801 & 0,019 & 0,077 & 0,808 & 0,019 & 0,126 & 0,883 \\
return on assets & $-1,064^{* * *}$ & 0,207 & 0,000 & $-1,064^{* * *}$ & 0,179 & 0,000 & $-1,064^{* * *}$ & 0,177 & 0,000 \\
return on equity & 0,013 & 0,013 & 0,323 & 0,013 & 0,013 & 0,321 & 0,013 & 0,013 & 0,301 \\
GDP Growth Rate & $-0,064$ & 0,071 & 0,366 & $-0,064$ & 0,057 & 0,261 & $-0,064$ & 0,126 & 0,610 \\
Bank Total credit & $0,218^{* * *}$ & 0,037 & 0,000 & $0,218^{* * *}$ & 0,026 & 0,000 & $0,218^{* * *}$ & 0,041 & 0,000 \\
Exchange rate & $0,000^{*}$ & 0,000 & 0,073 & 0,000 & 0,000 & 0,122 & $0,000^{*}$ & 0,000 & 0,086 \\
Money Supply growth rate & $0,065^{*}$ & 0,034 & 0,055 & $0,065^{* *}$ & 0,026 & 0,015 & $0,065^{*}$ & 0,038 & 0,089 \\
Constant & 29,486 & 2,282 & 0,000 & 29,486 & 1,926 & 0,000 & 29,486 & 2,719 & 0,000 \\
Wald chi2(11) & 925,7 & & & 1598,69 & & & 126,65 & & \\
Prob> chi2 & 0,000 & & & 0,000 & & & & & \\
R-squared & & & 0,7834 & & & &
\end{tabular}

Note: ${ }^{*}$ represents significance level of $10 \%$, ** represents significance level of $5 \%$ and $* * *$ represents significance level of $1 \%$

Source: Author's computation

Further, the individual relationship between the non-performing loans and the exchange rate shows a positive and statistically significant relationship on non-performing loans in the MINT economies. This result agrees with most of the previous literature that postulates a direct relationship between the two. This connotes that an increase in exchange rate tends to increase non-performing loans as the cost of servicing foreign-denominated loans rises (Beck et al., 2013). Also, capital adequacy ratio appears to have one of the highest impacts on non-performing loans. It is significant in all the models. This is in support of literature that tied non-performing loans to moral hazard (see Sinkey \& Greenawalt, 1991; Berger \& DeYoung, 1997). The implication is that the bank-specific factors, such as capital adequacy ratio, are an important variable that can be used to control the volume of non-performing loans in the banking sector (see Louzis et al., 2012). The higher the capital adequacy ratio, the more guaranteed the corporate existence of the bank and the less the management tendency to go after low-quality loans. Also, among the bank specific variables, total credit and return on assets both have a significant impact on non-performing loans. This is an indication that the volume of credit in the economy alongside and the return on assets of the banks have strong links with nonperforming loans in the MINT economies. Indeed, Godlewski (2006) used return on assets as proxy for bank performance and concluded that non-performing loans are negatively related to return on assets. The tendency is that managers whose bank's 'ROA' is high are not motivated to go after low-quality assets in desperation to cover performance. Inefficient bank managers tend to shore up profitability performance by engaging in loans of low quality.

A supposed exogenous (institutional) variable included in the model, which is the corruption index, corroborates findings in literature showing a positive and very significant relationship with the nonperforming loans in both models. Indeed, it has the highest coefficients of all the determinants of nonperforming loans in the MINT economies. Even though the sign is negative, the correct interpretation lies in the description of the data by Transparency International which ranks corruption from 1 (highest corruption level) to 10 (lowest corruption level). Hence this means the higher the ranking towards lowest corruption level, the lower the level of non-performing loans. Again, several studies in the literature have pointed out that the prevalence of corruption in many developing countries in the world is aggravating the problem of non-performing loans in the banking sectors of these economies. They show that the MINT economies are not exempted (see Boudriga et al., 2010; Goel and Hasan, 2011; Ahmad, 2013). Considering all the results, it appears that lending rate, exchange rate, money supply growth rate, corruption, capital adequacy ratio, total credit, liquidity ratio and return on assets are likely to be strong determinants of non-performing loans in the MINT economies. 


\section{Conclusion and Implications}

The study has empirically studied the determinants of non-performing loans in the MINT economies. Ultimately, the study confirms that bank capital adequacy ratio, return on assets, returnon equity, bank liquidity, total credit, lending rate, exchange rate, money supply growth rate, corruption and GDP levels are important determinants of non-performing loans in the MINT economies. They account for about83\% variation in the volume of non-performing loans in the MINT economies. Again, capital adequacy ratio, bank liquidity and return on assets are the strongest bank-specific variables that affect non-performing loans. This underscores the importance of avoidance of moral hazard as a panacea for non-performing loans in the banks. Also, a rise in bank performance as measured by return on assets puts less pressure on managers to book loans recklessly, hence leading to a reduction in non-performing loans. Another conclusion that can be drawn from the study is that a lending rate increase can aggravate the problem of non-performing loans in the MINT economies. This implies that an excessive interest rate charged on loans by banks contributes to the upsurge of non-performing loans. The literature reveals that borrowers become more resistant to loan repayment in this situation; in other words, loan defaulters are most likely to be on the rise with an increase in the lending rate when the capacity to pay is encumbered. Concluding on the determinants, sinceinstitutional, macroeconomic and bank-specific variables have shown up as determinants of nonperforming loans, these identified factors have to be combined in order to properly model non-performing loans in the MINT economies.

Finally, since the results have shown that there is likelihood of cross-sectional dependence, an area for further research will be to individually appraise each economy and find out what peculiar features might distinguish them from one another in terms of non-performing loans and the MINT economies. On policy implications, we recommend that policy-makers in these countries should focus more on the major determinants identified in this study and proactively bring up policies that will rein-in the current observed growth in NPLs in order to avoid its undesired consequences.For instance, institutions should be strengthened in a manner that will encourage transparency and discourage corruption. Also, subject to policy-consistency and availability of options to the monetary authorities in 'MINT' countries, policy choices should tilt more towards those that will lower interest rate because of its direct influence on lending rates. Furthermore, reasonable stringent measures should be applied to the growth of money supply and its various drivers. Finally, in terms of bank-specific determinants, the banking supervisory agencies in 'MINT' countries should bolster capital and liquidity of banks to benchmarked standards. This creates the requisite shockabsorbers against NPLs' rise and its attendant consequences. On academic front, MINTs align with the findings of some authors in the past who were of the opinion that most economic blocs, such as BRICS and the Organisation for Economic Co-operation and Development (OECD)have individual peculiarities that distinguish them from one another.

\section{References}

Adeyemi, B. (2011). Bank failure in Nigeria: A consequence of capital inadequacy, lack of transparency and non-performing loans. Banks and Bank Systems, 6(1), 99-109.

Ahmad, F. (2013).Corruption and information sharing as determinants of non-performing loans. Business Systems Research, 34(1), 87-98.

Akpan, U. S., Isihak, S. R. \& Asongu, S. A. (2014). Determinants of foreign direct investment in fast-growing economies: A Study of BRICS and MINT. African Governance and Development Institute. (WP/14/002).

Aminu, B., Dogarawa, A. B. \& Sabari, M. H. (2014). Impact of Loan Loss Provisioning On Banks Credits in Nigeria during Consolidation Period. International Journal of Business and Management Invention, $3(11), 9-19$

Anderson, K. (2011). Financial Stability in the ECCU: Developing Early Warning Systems and a Financial Stability Index.

Andrews, M., Schank, T. \& Upward, R. (2006).Practical fixed-effects estimation methods for the three-way error-components model. Stata Journal, 6(4), 461.

Arellano, M. \& Stephen, B. (1991). Some tests of specification for panel data: Monte Carlo evidence and an application to employment equations. The Review of Economic Studies, 58(2), 277-297. 
Asongu, S. A. \& Kodila-Tedika, O. (2015). Conditional determinants of FDI in fast emerging economies: an instrumental quantile regression approach.African Governance and Development Institute Working Paper, (15/003).

Auffhammer, M., Hsiang, S. M., Schlenker, W. \& Sobel, A. (2013). Using weather data and climate model output in economic analyses of climate change. Review of Environmental Economics and Policy, ret016.

Bai, J. (2009). Panel data models with interactive fixed effects. Econometrica, 77(4), 1229-1279.

Barseghyan L. (2010). Non-performing loans, prospective bailouts, and Japan's slowdown. Journal of Monetary Economics, 57(7), 873-890

Baum, C. F., Schaffer, M. E. \& Stillman, S. (2007). Enhanced routines for instrumental variables/GMM estimation and testing. Stata Journal, 7(4), 465-506.

Beck, R., Jakubik, P. \& Piloiu, A. (2013). Non-performing loans: What matters in addition to the economic cycle? papers.ssrn.com

Beck, N. \& Katz, J. N. (1995). What to do (and not to do) with time-series cross-section data. American political science review, 89(03), 634-647.

Benavente, J. M., Johnson, C. A. \& Morande, F. G. (2003). Debt composition and balance sheet effects of exchange rate depreciations: A firm-level analysis for Chile. Emerging Markets Review, 4(4), 397-416.

Berger, A. N. \& DeYoung, R. (1997). Problem loans and cost efficiency in commercial banks. Journal of Banking \& Finance, 21(6), 849-870.

Blundell, R. \& Bond, S. (1998). Initial conditions and moment restrictions in dynamic panel data models. Journal of Econometrics, 87(1), 115-143.

Blundell, R., Bond, S. \& Windmeijer, F. (2000). Estimation in dynamic panel data models: improving on the performance of the standard GMM estimator (No. W00/12). IFS working papers.

Boudriga, A., Taktak, N. B. \& Jellouli, S. (2010). Bank specific, business and institutional environment determinants of banks nonperforming loans: Evidence from MENA countries. Economic Research Forum. (Working paperseries n0.547).

Breuer, J. B. (2006). Problem bank loans, conflicts of interest, and institutions. Journal of Financial Stability, 2(3), 266-285.

Carney, R. (ed.). (2009). Lessons from the Asian Financial Crisis. New York: Routledge.

Chow, G. C. \& Lin, A. L. (1971). Best linear unbiased interpolation, distribution, and extrapolation of time series by related series. The review of Economics and Statistics, 2, 372-375.

Cochran, J. P. \& Call, S. T. (2000). Free banking and credit creation: Implications for business cycle theory. Quarterly Journal of Austrian Economics, 3(3), 35-50

De Luna-Martinez, J. (2000). Management and Resolution of Banking Crises. World Bank Discussion Paper, (413).

Desmet, K. (2000). Accounting for the Mexican banking crisis. Emerging Markets Review, 1(2), 165-181.

Driscoll, J. C. \& Kraay, A. C. (1998). Consistent covariance matrix estimation with spatially dependent panel data. Review of economics and statistics, 80(4), 549-560.

Durotoye, A. (2014). The Crisis of Youth Unemployment in the MINT Countries: Causes, Consequences and Corrections. European Journal of Business and Management, 16(24), 123-135.

Fofack, H. (2005). Nonperforming loans in Sub-Saharan Africa: Causal analysis and macroeconomic implications. World Bank Policy Research. (Working paper n0. 3769).

Friedman, J. (1994). Cultural identity and global process. Sage. Volume 31.

Eigner, F. (2009) Dynamic Panel Data Methods for cross-section panels. University of Vienna Press.homepage.univie.ac.at/robert.kunst/pres09_pan_eigner.pdf

Godlewski, C. J. (2006). Regulatory and Institutional Determinants of Credit Risk Taking and a Bank's Default in Emerging Market Economies A Two-Step Approach. Journal of Emerging Market Finance, 5(2), 183-206.

Goel, R. K. \& Hasan, I. (2011). Economy-wide corruption and bad loans in banking: international evidence. Applied Financial Economics 21(7), 455-461.

Greenidge, K. \& Grosvenor, T. (2010).Forecasting non-performing loans in Barbados. Journal of Business, Finance and Economics in Emerging Economies, 5, 80-107.

Griffith, D. A. \& Chun, Y. (2014). An eigenvector spatial filtering contribution to short range regional population forecasting. Economics and Business Letters, 3(4), 208-217.

Gujarati, D. N. \& Sangeetha, K. (2007). Basic Econometrics. New Delhi: Tata McGraw Hill. 
Hasan, I. \& Wall, L. D. (2004). 'Determinants of the Loan Loss Allowance: Some Cross-Country Comparisons', The Financial Review, 39, 129-152.

Hausman, J. A. (1978). Specification tests in econometrics. Econometrica: Journal of the Econometric Society, 2, 1251-1271.

Hayes, A. F. \& Preacher, K. J. (2014). Statistical mediation analysis with a multicategorical independent variable. British Journal of Mathematical and Statistical Psychology, 67(3), 451-470.

Hedges, L. V. \& Vevea, J. L. (1998). Fixed-and random-effects models in meta-analysis. Psychological methods, $3(4), 486$.

Hoechle, D. (2007). Robust standard errors for panel regressions with cross-sectional dependence. Stata Journal, 7(3), 281.

Hsiao, C. \& Tahmiscioglu, A. K. (2008). Estimation of dynamic panel data models with both individual and time-specific effects. Journal of Statistical Planning and Inference, 138(9), 2698-2721.

Hu, J. L., Li, Y. \& Chiu, Y. H. (2004). Ownership and nonperforming loans: Evidence from Taiwan's banks. The Developing Economies, 42(3), 405-420.

International Monetary Fund. (2004). www.imf.org/external/pubs/ft/gfsr/2004/02

International Monetary Fund. (2010). https://www.imf.org/external/pubs/ft/gfsr/2010/02/pdf/text.pdf

International Monetary Fund. (2013). https://www.imf.org/External/Pubs/FT/GFSR/2013/01/pdf/text.pdf

Jakubik, P. \& Moinescu, B. (2015). Assessing optimal credit growth for an emerging banking system. Economic Systems, 39(4), 577-591.

Jiménez, G., Ongena, S., Peydró, J. L. \& Saurina, J. (2014). Hazardous Times for Monetary Policy: What Do Twenty-Three Million Bank Loans Say About the Effects of Monetary Policy on Credit Risk-Taking? Econometrica, 82(2), 463-505.

Karabulut, G., Bilgin, M. H. \& Danisoglu, A. C. (2010). Determinants of currency crises in Turkey: some empirical evidence. Emerging Markets Finance and Trade, 46(sup1), 51-58.

Keeton, W. R. \& Morris, C. S. (1987). Why Do Banks'sLoan Losses Differ? Economic Review, 72(5), 3-21.

Kezdi, G. (2004). Robust standard error estimation in fixed-effects panel models. Hungarian Statistical Review, 9, 95-116.

Klein, N. (2013). Non-performing loans in CESEE: Determinants and impact on macroeconomic performance. N Klein - 2013 - papers.ssrn.com.

Kokotović, F. \& Kurečić, P. (2016). The MINT Countries: A Regression Analysis of the Selected Economic Features. In 14th International Scientific Conference on Economic and Social Development.

Krueger, A. \&Tornell, A. (1999). The role of bank restructuring in recovering from crises: Mexico 1995-98. National Bureau of Economic Research Cambridge, MA. (NBER working paper no. 7402) AO Krueger, A Tornell - NBER Working Paper, 1999 - papers.ssrn.com

Larcker, D. F. \& Rusticus, T. O. (2010). On the use of instrumental variables in accounting research. Journal of Accounting and Economics, 49(3), 186-205.

Leaven, L. \& Valencia, F. (2010). Resolution of Banking Crises: The Good, the Bad, and the Ugly, IMF Working Paper 10/146.

Louzis, D. P., Vouldis, A.T. \& Metaxas, V. L. (2012). Macroeconomic and bank-specific determinants of nonperforming loans in Greece: A comparative study of mortgage, business and consumer loan portfolios. Journal of Banking \& Finance, 36(4), 1012-1027.

Maddala, G. S. (1977). Identification and estimation problems in limited dependent variable models. In Natural Resources, Uncertainty and General Equilibrium Systems: Essays in Memory of Rafael Lusky (pp. 219-239). Academic Press New York.

Makin, J. H. (2007). Risk and Return in Subprime Mortgages. Washington, DC: American Enterprise Institute.

Makri, V., Tsagkanos, A. \& Bella, A. (2014). Determinants of non-performing loans: The case of Eurozone. Panoeconomicus, 61(2), 191

Mishkin, F. S. (1999). Lessons from the Asian crisis. Journal of International Money and Finance, 18(4), 709723.

Moinescu, B. G. (2012). Determinants of nonperforming loans in Central and Eastern European Countries: Macroeconomic indicators and credit discipline. Review of Economic and Business Studies, 10, 47-58.

Mutl, J. \& Pfaffermayr, M. (2011). "The Hausman test in a Cliff and Ord panel model. The Econometrics Journal 14(1), 48-76. 
Nerlove, M. \& Balestra, P. (1996). Formulation and estimation of econometric models for panel data. In The econometrics of panel data, $2 d$ rev. ed., edited by L. Mátyás, and P. Sevestre, 3-22. Dordrecht, the Netherlands: Kluwer

Nkusu, M. (2011). Nonperforming loans and macrofinancial vulnerabilities in advanced economies. IMF Working Papers, 1-27.

O'Neill, J. (2014). The MINT Countries: Next Economic Giants. BBC News Online, 6.

Özatay, F., Sak, G., Garber, P. \& Ghosh, A. (2002). Banking Sector Fragility and Turkey's 2000-01 Financial Crisis [with Comments and Discussion]. Brookings Trade Forum, 1, 121-172.

Öztürk, Z. \& Yıldırım, E. (2015). MINT ÜlkelerindeÇevresel Kuznets Eğrisi: UzunDönem Panel NedensellikTestindenKanıtlar. AİBÜ-İIBB EkonomikveSosyalAraştırmalarDergisi.

Pao, S. H., Lin, J. H. \& Chang, S. H. (2011). The effects of the change of bond insurance premium and capital regulatory ratio on loan and deposit rates: an option-pricing model. WSEAS Transactions on Mathematics, 10(7), 219-228.

Reinhart, C. M. \& Rogoff, K. S., (2010). Growth in a time of debt (digest summary). American Economic Review, $100(2), 573-578$

Rowland, P. \& José Luis Torres T. (2004). Determinants of spread and creditworthiness for emerging market sovereign debt: A panel data study. Banco de la República, Subgerencia de Estudios Económicos, Bogota, Columbia.

Rudd, M. A. (2000). Live long and prosper: collective action, social capital and social vision. Ecological economics, 34(1), 131-144.

Sinkey Jr, J. F. \& Greenawalt, M. B. (1991). Loan-loss experience and risk-taking behavior at large commercial banks. Journal of Financial Services Research, 5(1), 43-59.

Škarica, B. (2013). Determinants ofnon-performing loans in Central and Eastern European countries.EFZG Working Paper Series/EFZG Serija članaka u nastajanju, (07), 1-19.

Somoye, R. O. C. (2010). The Variation of Risks on Non-Performing Loans on Bank Performances in Nigeria. Indian Journal of Economics \& Business, 9(1).

Stiglitz, J. E. (1989), Markets, market failures, and development. The American Economic Review, 79(2), 197203

Vodova, P. (2011). Liquidity of Czech commercial banks and its determinants. International Journal of Mathematical Models and Methods in Applied Sciences, 5(6), 1060-1067

World Bank. (2014). Finance for Growth - Policy Choices in a Volatile World. World Bank Research Report. Washington, DC: Oxford University Press.

Roodman, D. (2009). Oxford Bulletin of Economics and statistics- Wiley Online Library

Wilson, D. \& Purushothaman, R. (2003). Dreaming with BRICs: The path to 2050 (Vol. 99). Goldman, Sachs \& Company.

Yang, L. (2003). The Asian financial crisis and non-performing loans: evidence from commercial banks in Taiwan. International Journal of Management, 20(1), 69

Zeng, S. (2012). Bank non-performing loans (NPLS): A dynamic model and analysis in China. Modern Economy, $3,100-110$. 